\title{
Antimicrobial Activities of Some Medicinal Plants Against Multiresistants Microorganisms Causing Urogenital Tract Infections in Cameroon
}

\author{
Tabouguia Octavie Merveille ${ }^{1,6}$, Zofou Denis ${ }^{2}$, Njouendou Jelil Abdel ${ }^{3,7}$, Anneh Abegewi Ursula ${ }^{3}$, \\ Aurelien Fleury A. Moumbock Adie ${ }^{4}$, Babiaka Borakoraeye Smith ${ }^{4}$, Nganyewo Allen Zipoh ${ }^{4}$, \\ Yong Ngwain Joseph ${ }^{4}$, Nde Fon Peter ${ }^{5}$, Penlap Beng Veronique ${ }^{6}$, Assob Nguedia Jules Clement ${ }^{1, *}$ \\ ${ }^{1}$ Department of Medical Laboratory Sciences, Faculty of Health Sciences, University of Buea, SW Region, Cameroon \\ ${ }^{2}$ Department of Biochemistry, Faculty of Science, University of Buea, SW Region, Cameroon \\ ${ }^{3}$ Department of Microbiology and Parasitology, Faculty of Science, University of Buea, SW Region, Cameroon \\ ${ }^{4}$ Department of Chemistry, Faculty of Science, University of Buea, SW, Cameroon \\ ${ }^{5}$ Department of Public Health and Hygiene, Faculty of Health Sciences, University of Buea, SW Region, Cameroon \\ ${ }^{6}$ Department of Biochemistry, Faculty of Science, University of Yaounde I, Yaounde, Cameroon \\ ${ }^{7}$ Research Foundation for Tropical Diseases and Environment (REFOTDE), SW Region, Cameroon
}

\section{Email address:}

juleclement@yahoo.fr (A. N. J. Clement)

${ }^{*}$ Corresponding author

\section{To cite this article:}

Tabouguia Octavie Merveille, Zofou Denis, Njouendou Jelil Abdel, Anneh Abegewi Ursula, Aurelien Fleury A. Moumbock Adie, Babiaka Borakoraeye Smith, Nganyewo Allen Zipoh, Yong Ngwain Joseph, Nde Fon Peter, Penlap Beng Veronique, Assob Nguedia Jules Clement. Antimicrobial Activities of Some Medicinal Plants Against Multiresistants Microorganisms Causing Urogenital Tract Infections in Cameroon. Journal of Diseases and Medicinal Plants. Vol. 3, No. 2, 2017, pp. 33-41. doi: 10.11648/j.jdmp.20170302.12

Received: January 2, 2017; Accepted: January 7, 2017; Published: March 30, 2017

\begin{abstract}
Urogenital tract infections remain a serious global treat especially in women. The control of these infections is increasingly complicated due to development of resistance against available drugs. Therefore a perpetual search of new antimicrobial molecules is needed to face the challenge of microbial resistance. This study was initiated to screen the antimicrobial activities of methanol extracts of nine Cameroonian medicinal plants, used for the treatment of infectious diseases, against multiresistant pathogens isolated from urogenital infected patients. The plants included: Cussonia arborea, Dissotis longipetala, Lonchocarpus sepium, Nauclea pobeguinii, Picralima nitida, Rumex abyssinicus, Rumex berqueatii, Sapium ellypticum, Psorospermum febrifigum, They were tested on seven strains including six clinical isolates (Escherichia coli, Proteus vulgaris, Providencia stuartii, Pseudomonas aeruginosa, Staphylococcus saprophiticus, Candida krusei) and one reference strain (E. coli JM109). Clinical strains were checked for their multiresistance using disc diffusion method. The antimicrobial activities were determined by agar well diffusion method. MICs were determined using microdilution assay. The phytochemical screening of plants was also done. All the bacteria strains were found to be multidrug-resistant (MDR) against at least 7 of the 12 antibiotics tested. Antimicrobial activities demonstrated that 6/9 (SE, DL, RA, RB, PN, LS) plants were active on at least six microorganisms. MICs ranged from 0.125 to $128 \mathrm{mg} / \mathrm{ml}$ for crude extracts, from 0.5 to $0.16 \mu \mathrm{g} / \mathrm{ml}$ for gentamicin and was $0,002 \mathrm{mg} / \mathrm{ml}$ for fluconazole. One extract (NP) which showed limited results on agar, inhibited the growth of all the strains with MICs ranging from 1 to $16 \mathrm{mg} / \mathrm{ml}$ showing a limited activity of this extract on agar. We found that four extracts (SE, NP, RA, DL) have significant activities since they presented MICs $\leq 8 \mathrm{mg} / \mathrm{ml}$ on at least 5 tested microorganism individually. Findings from phytochemical screening showed that most active extracts contain tannins, alkaloids and saponins which could be responsible of these activities.
\end{abstract}

Keywords: Urogenital Infections, Sapium, Nauclea, Dissotis, Rumex, Picralima, Antimicrobial Activities 


\section{Introduction}

Urogenital tract infections (UGI) remain a serious global health threat. Despite the continuous efforts, World Health Organization (WHO) estimated the incidence in 2013 at about 500 million new cases each day worldwide [1]. These infections can have serious consequences including damages of reproductive organs leading to infertility, social rejection and death. They are also the first infections involved in neonatal deaths and complications related to pregnancy and childbirth [2]. Furthermore, the resistance of pathogens against antimicrobial therapeutics is increasing all over the world and remains a great challenge in the eradication of pathogens. Hence, the fight against infectious diseases in general and urogenital tract infections in particular has been seriously compromised by the ineffectiveness of most available and cheaper treatments due to microbial resistance, and by the unavailability and non-affordability of many treatments [3]. This has recently led to the screening of hundreds of plants derived products, in order to discover novel antimicrobial agents which could be the potential solution to pathogens resistance, considering the wide range of secondary metabolites they usually contains [4]. Cussonia arborea (CA), Dissotis longipetala (DL), Lonchocarpus sepium (LS), Nauclea pobeguinii (NP), Picralima nitida (PN), Rumex abyssinicus (RA), Rumex berqueatii (RB), Sapium ellypticum (SE), Psorospermum febrifigum (PF) are nine (09) medicinal plants of the Cameroonian pharmacopeia used traditionally for the treatment of a wide range of infectious diseases including urogenital tract infections; they may therefore possess antimicrobial activities. It is in this view that this work was initiated aiming to assess the antimicrobial activities of these nine Cameroonian pharmacopeia plants commonly used against infectious diseases.

\section{Material and Methods}

\subsection{Plant Material}

The different plant parts were harvested in West and North West regions of Cameroon. The various plants were identified at the National Herbarium of Cameroon (NHC), where voucher specimens were deposited with voucher number. Detailed information on each medicinal plant is given in table 1.

\subsection{Preparation of Extracts}

Fresh plant materials were collected and dried at room temperature in an aerated laboratory and pulverized. Five (05) $\mathrm{kg}$ of the powder of each plant were then macerated in 13.5 L of methanol for 48 hours to give about $7.5 \mathrm{~L}$ of extract after filtration. The filtrate was evaporated on a Buchi rotary evaporator and the extraction yields of different crude extracts were determined (table 1). An aliquot of each extract was used for antimicrobial studies while the remaining portion was kept for further studies.

\subsection{Phytochemical Screening}

Qualitative phytochemical tests were performed for methanolic extracts of all the plants to identify the various classes of phyto-constituents, according to the protocols described by [5].

\subsection{Antimicrobial Activities}

\subsubsection{Microbial Strains}

The plants were tested on seven microbial strains including six clinical strains (Escherichia coli, Proteus vulgaris, Providencia stuartii, Pseudomonas aeruginosa, Staphylococcus saprophiticus, and Candida krusei) and one reference strain (E. coli JM109). While clinical strains were obtained from two laboratories, the Laquintinie Hospital Douala (Littoral region - Cameroon) and Solidarity Clinic, Buea, South-West region Cameroon. They were all from urinary or genital tracts specimens (urine, vaginal smear, and sperm) from symptomatic patients presenting urogenital infections (for which the consulting physician requested for an antibiogram). Reference strain was obtained from BEI resources, NIAID, NIH, Manassas USA.

\subsubsection{Characterization of Microbial Strains}

Clinical isolates were characterized and identified with microscopic, cultural and biochemical methods [6].

After the gram stain, bacteria isolates were grown on various media. Gram negative bacteria were cultured on MacConkey and Cled agar, while Gram positive were cultured on Mannitol Salt Agar.

Gram negative bacteria alongside with the reference strain E. coli JM109 were characterized biochemically using the following test:

- The Kliger iron agar test, was carried out to detect the ability of the microorganism to ferment glucose and /or lactose with/without gas production, it also showed the ability of the organism to produce $\mathrm{SH} 2$ gas. After incubation, red/yellow slant indicated negative/positive lactose, while a red/yellow bottom indicated a negative/positive glucose. Gas production was manifested by the presence of bubbles in the tube, while the sulfide production was manifested by a back deposit at to bottom of the tube.

- Citrate test, which permitted us to determine the ability of the microorganism to metabolize only citrate as it sole carbon source. The change in color media from green to blue showed a citrate positive.

- Urea test: it was used to determine the capacity of the bacteria to hydrolyze urea using the enzyme urease. The change in color of the broth from orange to pink indicated a urease positive.

- Indole test: it detects the capacity of the bacteria to produce the enzyme tryptophanase, which convert the amino acid, tryptophane to indole. Indole reacts with added Kovac's reagent to form rosindole dye which is 
red in color (indole + )

- Gram positive bacteria alongside with the reference strain S. aureus RN4220 was characterized biochemically using the following tests:

- Catalase test: This test was used to identify organisms that produce the enzyme, catalase. This enzyme detoxifies hydrogen peroxide by breaking it down into water and oxygen gas. The bubbles resulting from production of oxygen gas clearly indicated a catalase positive result.

- Coagulase test: Coagulase is an enzyme that clots blood plasma. The test was performed on Gram-positive, catalase positive species to identify the coagulase positive Staphylococcus aureus. This test differentiates Staphylococcus aureus from other coagulase negative Staphylococcus species (coagulase negative Staphylococcus).

- For Candida: The sample was culture on Saboureaud chloramphenicol agar, and the isolate was tested for the evidence of production of germ tube in human serum, the test kit Integral System YEASTS (Liofilchem) permitted the identification of Candida krusei.

Tables 2 and 3 summarized the results obtained.

Table 1. Detailed information of medicinal plants used in this work.

\begin{tabular}{|c|c|c|c|c|}
\hline Scientific name of the plant & Family of the plant & Part used & Extraction yield (\%) & Voucher number \\
\hline Cussonia arborea (CA) & Araliaceae & Bark & 13.43 & $39978 / \mathrm{HNC}$ \\
\hline Dissotis longipetala (DL) & Melastomataceae & Bark & 9.00 & $40925 / \mathrm{HNC}$ \\
\hline Lonchocarpus sepium (LS) & Fabaceae & Bark & 8.00 & $76230 / \mathrm{HNC}$ \\
\hline Nauclea pobeguinii (NP) & Rubiaceae & Bark & 10.98 & $504710 / \mathrm{HNC}$ \\
\hline Picralima nitida $(\mathrm{PN})$ & Apocynaceae & Bark & 14.08 & $565411 / \mathrm{HNC}$ \\
\hline Rumex abyssinicus (RA) & Polygonaceae & Bulbs & 17 & 27239/SRF Cam \\
\hline Rumex berqueatii De Wild (RB) & Polygonaceae & Bulbs & 14 & 7665/SRF Cam. \\
\hline Psorospermum febrifigum (PF) & Guttiferae & Stem bark & 10.40 & $36617 / \mathrm{HNC}$ \\
\hline
\end{tabular}

Table 2. Biochemical characterization results of Gram negative bacteria.

\begin{tabular}{|c|c|c|c|c|c|c|c|c|}
\hline Tested strains & $\begin{array}{l}\text { Fermentation } \\
\text { Glucose }\end{array}$ & $\begin{array}{l}\text { Fermentation } \\
\text { Lactose } \\
\end{array}$ & $\begin{array}{l}\text { Production } \\
\text { SH2 }\end{array}$ & $\begin{array}{l}\text { Production } \\
\text { gaz }\end{array}$ & Urease & Indol & citrate & Presumptive bacteria species \\
\hline E coli JM109 & + & + & \multirow{2}{*}{-} & + & - & + & _- & \multirow{3}{*}{ E. coli } \\
\hline$M C K 1$ & + & + & & + & - & + & - & \\
\hline$M C K 2$ & + & - & $\overline{+}$ & - & $\overline{+}$ & + & - & \\
\hline MCK9 & + & - & _- & $\overline{+}$ & - & + & $\overline{+}$ & Providencia stuartii \\
\hline CLED2 & & & & & & + & + & Pseudomonas aeruginosa \\
\hline
\end{tabular}

Table 3. Results of biochemical characterization of gram Positive bacteria.

\begin{tabular}{lllll}
\hline Tested strains & Catalase & Coagulase & Yellow colonies on MSA & Presumptive bacteria specie \\
\hline S. aureus RN4220 & + & + & + & Coagulase negative Staphylococcus (CNS) S. saprophiticus \\
MSA1 & + & - & + & C
\end{tabular}

\subsubsection{Antibiogram}

The antibiogram of clinical isolates was carried out in order to select resistant strains. The antibiotics were selected from a list provided by two medical doctors. They were those currently prescribed to patients suffering from urogenital tract infections. The prices were attributed to the antibiotics and only the cheaper once were selected for this study. The following antibiotics were selected: Ciprofloxacin, Norfloxacin, Erytromycin, Cefotaxime, Doxycycline, Bactrim, Metronidazole, Amoxicillin + clavunilic acid and Chloramphenicol for bacteria species; Nystatin, Fluconazole, Griseofluvin and Ketoconazole for candida specie.

The antibiogram of clinical isolates was then performed using disc diffusion method describe by [7]. Briefly, an inoculum of approximately $10^{8} \mathrm{CFU} / \mathrm{ml}$ was swabbed on dried poured plate. The commercial antibiotics discs from the above list were delicately dropped on the surface of plates and allowed at room temperature for pre-diffusion for 15 minutes, and then the plates were incubated at $37^{\circ} \mathrm{C}$ for 24 hours for bacteria and for 48 hours for Candida. After incubation, the diameters of inhibition zone were measured and interpreted using Bauer chart on antibiogram result [7] and the strains were classified as resistant (R) intermediate (I) or sensitive (S) against each antibiotics (see table 5 below).

\subsubsection{Antimicrobial Tests}

(a) Inhibition zone diameters

The susceptibility tests were performed using the agar well diffusion method described by [4] with slight modifications. Stock solutions of test samples were prepared in $10 \% \mathrm{v} / \mathrm{v}$ dimethylsulfoxide (DMSO) solution at concentrations of 50 $\mathrm{mg} / \mathrm{ml}$ (for crude extract) and $40 \mu \mathrm{g} / \mathrm{ml}$ for gentamicin and fluconazole used as positive control. The inocula were prepared by dissolving 3 to 5 colonies in sterile saline $(0.9 \%$ $\mathrm{NaCl}$ ) from a 24 hours culture plates for bacteria and 48 hours for Candida, and the turbidity was then adjusted to match 0,5 Mc Farland standard turbidity. $20 \mathrm{ml}$ of Muller Hinton Agar was poured into each of the $90 \mathrm{~mm}$ petri dishes and inoculated using a swap tip. The medium was punched with six millimeters diameter wells and filled with $80 \mu \mathrm{l}$ of the test sample. Aqueous DMSO $10 \% \mathrm{v} / \mathrm{v}$ was tested as negative control. After a pre-diffusion of 1 hour, the plates 
were incubated at $37 \pm 1^{\circ} \mathrm{C}$ for 24 hours for bacteria species and for 48 hours for Candida and inhibition zones were measured. All tests were done in triplicate and the results were recorded as the mean of diameter of zones of inhibition.

(b) Minimum Inhibitory Concentration (MIC)

MICs were determined by broth microdilution technique using 96-well plates as previously described by [8]. Culture media (nutrient broth) were supplemented with $0.2 \%$ of glucose and $0.005 \%$ phenol red end point indicator. The wells were filled with $100 \mu \mathrm{L}$ of broth, and $100 \mu \mathrm{L}$ of extract was added in triplicate to the first column previously prepared in DMSO to make a final concentration of 512 $\mathrm{mg} / \mathrm{ml}$. Successive dilutions were done by transferring $100 \mu \mathrm{l}$ of the mixture from the first well to the eleventh well. An aliquot $(100 \mu \mathrm{l})$ was discarded from the eleventh well. The twelfth well served as control since no sample (extract, or reference antibiotics) was added in it. Finally, $100 \mu 1$ of a standardize inoculum at $10^{6} \mathrm{CFU} / \mathrm{ml}$ was added in each test well for Gram negative bacteria and $10^{5} \mathrm{CFU} / \mathrm{ml}$ for Gram positive and yeasts. The final concentration of the extracts used to evaluate the antimicrobial activity ranged from 128 to $0.125 \mathrm{mg} / \mathrm{ml}$ and from 128 to $0.125 \mu \mathrm{g} / \mathrm{ml}$ for the reference drugs. Tests were incubated aerobically at $37 \pm 1^{\circ} \mathrm{C}$ for 24 and 48 hours for bacteria and Candida species respectively. The end point was revealed by a color change of the indicator from red to pink or to yellow by comparing the test wells to control wells (media, diluted extract and distilled water). The MIC was considered as the lowest concentration of sample that could prevent visible growth of microorganism (no change of the indicator). The results were recorded as mean of MICs.

(c) Minimum Microbicidal concentration [9]

A loopful of the test mixture was removed from each MIC well that showed no growth, inoculated onto free MuellerHinton agar plate, incubated $\left(37^{\circ} \mathrm{C}, 24-48 \mathrm{~h}\right)$, and inspected for presence of colonies indicating growth. The minimal microbicidal concentration was the lowest concentration of extract that showed no microbial (bacterial of fungi) growth.

\section{(d) $\mathrm{MMC} / \mathrm{MIC}$ ratio}

The MMC/MIC ratio was calculated to find out if the microbial inhibition of plant extract was microbicidal or micro-static. Therefore, when $\mathrm{MMC} / \mathrm{MIC} \leq 4$, the inhibition was considered microbicidal, and when $\mathrm{MMC} / \mathrm{MIC} \geq 4$, the inhibition was considered micro-static [10].

\subsection{Statistical Analysis}

Excel was used to process data and statistical analysis were done using SPSS version 20 for window. Univariate Analysis of Variance test was used to compare means of diameter of inhibition.

\section{Results and Discussion}

\subsection{Extraction Yield}

The table 3 below shows the yields of extraction of the various plants. They vary between $8 \%$ and $17 \%$. The methanol was used to extract all the plants. The differences observed in the results show that the yield of extraction is proportional to the solubility of the plant's components in the extracting solvent. Therefore, the yield of extraction increases alongside with the solubility of plant components in the solvent.

\subsection{Phytochemical Screening Results}

The phytochemical screening results (table 4) showed that except PN, PF and CA, the rest of the studied plants were found to be very rich in tannins. This could explain the antimicrobial activities observed. The results also showed that these previous tree plants (PN, PF and CA) are found not to have most of the screened phytochemicals; this observation could also explain the poor antimicrobial activity displayed by these extracts. Indeed, the antimicrobial activity of extracts depends on the concentration the active components (secondary metabolites) it may contain [11].

Table 4. Phytochemical test screening results of methanolic extracts of plants.

\begin{tabular}{|c|c|c|c|c|c|c|}
\hline & Steroids & Alkaloids & Saponins & Tannins & Terpernoids & Flavonoids \\
\hline $\mathrm{CA}$ & - & - & - & - & + & - \\
\hline DL & - & + & + & +++++ & - & + \\
\hline LS & - & + & + & +++++++++ & - & - \\
\hline NP & ++++ & + & ++ & + & - & - \\
\hline PF & - & - & - & - & + & + \\
\hline PN & - & - & - & - & - & - \\
\hline RA & - & ++ & ++ & +++++ & + & - \\
\hline $\mathrm{RB}$ & - & ++ & + & ++ & + & - \\
\hline SE & - & + & +++ & +++++++++ & + & - \\
\hline
\end{tabular}

$(+)$ present and the number of $(+)$ increases with the intensity of the coloration (-) absent

\subsection{Antibiogram}

Table 5 presents the antibiogram (ATB) results. It shows that all the five clinical bacteria strains were resistant to at list five of the twelve antibiotics tested, showing the multiresistant character of those strains. P. stuartii was the most resistant strain followed by $P$. aeruginosa being resistant to eleven and to nine of the twelve tested antibiotics respectively. Concerning C. krusei, it was resistant to two of the 4 antifungal tested. This resistant character of clinical isolates could be related to the inappropriate use of antibiotics by patients, by non-respecting either dose or the duration of the treatment, the too frequent prescription of "broad-spectrum antibiotics", in place of a better targeted 
antibiotic this through more precise diagnosis or the unnecessary prescription of antibiotics for viral infection

against which they have no effect [12].

Table 5. Antibiogram results: inhibition zone diameter $(\mathrm{mm})$ of antibiotic discs on tested microorganism.

\begin{tabular}{|c|c|c|c|c|c|c|c|c|c|c|c|c|}
\hline Antibiotic/Antifungi & E. coli & & P. aerugit & & P. stuartii & & P. vulgart & & S. saprop & & C. krusei & \\
\hline AMC 30 & $12.8 \pm 2.5$ & $\mathrm{R}$ & $0.0 \pm 0.0$ & $\mathrm{R}$ & $0.0 \pm 0.0$ & $\mathrm{R}$ & $28.3 \pm 2.9$ & $\mathrm{~S}$ & $19.0 \pm 1.4$ & $\mathrm{~S}$ & - & - \\
\hline $\mathrm{C}: \mathrm{R} \leq 12 ; \mathrm{I}: 13-17 ; \mathrm{S} \geq 18$ & $23.0 \pm 0.0$ & S & $10.0 \pm 0.0$ & $\mathrm{R}$ & $0.0 \pm 0.0$ & $\mathrm{R}$ & $0.0 \pm 0.0$ & $\mathrm{R}$ & $10.0 \pm 0.0$ & $\mathrm{R}$ & - & - \\
\hline CIP 30: $\mathrm{R} \leq 15 ; \mathrm{I}: 16-20 ; \mathrm{S} \geq 21$ & $0.0 \pm 0.0$ & $\mathrm{R}$ & $30.0 \pm 0.0$ & $\mathrm{~S}$ & $20.0 \pm 0.7$ & I & $25.5 \pm 2.8$ & $\mathrm{~S}$ & $10.0 \pm 0.0$ & $\mathrm{R}$ & - & - \\
\hline CN 120: $\mathrm{R} \leq 12 ; \mathrm{I}: 13-14 ; \mathrm{S} \geq 15$ & $21.0 \pm 0.0$ & S & $23.0 \pm 0.0$ & $\mathrm{~S}$ & $18.0 \pm 0.0$ & $\mathrm{~S}$ & $20.0 \pm 0.0$ & $\mathrm{~S}$ & $20.0 \pm 0.0$ & $\mathrm{~S}$ & - & - \\
\hline CRO $30 \mathrm{R} \leq 14 ; \mathrm{I}: 15-22 ; \mathrm{S} \geq 23$ & $20.0 \pm 0.0$ & I & $0.0 \pm 0.0$ & $\mathrm{R}$ & $0.0 \pm 0.0$ & $\mathrm{R}$ & $26.0 \pm 0.0$ & $\mathrm{~S}$ & $0.0 \pm 0.0$ & $\mathrm{R}$ & - & - \\
\hline CTX 30: R $\leq 14 ; \mathrm{I}: 15-22 ; \mathrm{S} \geq 23$ & $21.0 \pm 1.4$ & I & $0.0 \pm 0.0$ & $\mathrm{R}$ & $11.0 \pm 1.4$ & $\mathrm{R}$ & $31.3 \pm 1.2$ & $\mathrm{~S}$ & $12.5 \pm 1.7$ & $\mathrm{R}$ & - & - \\
\hline D0 30: R $\leq 14 ; \mathrm{I}: 15-18 ; \mathrm{S} \geq 19$ & $0.0 \pm 0.0$ & $\mathrm{R}$ & $0.0 \pm 0.0$ & $\mathrm{R}$ & $0.0 \pm 0.0$ & $\mathrm{R}$ & $0.0 \pm 0.0$ & $\mathrm{R}$ & $18.7 \pm 2.3$ & I & - & - \\
\hline MET 50 & $0.0 \pm 0.0$ & $\mathrm{R}$ & $0.0 \pm 0.0$ & $\mathrm{R}$ & $0.0 \pm 0.0$ & $\mathrm{R}$ & $0.0 \pm 0.0$ & $\mathrm{R}$ & $0.0 \pm 0.0$ & $\mathrm{R}$ & - & - \\
\hline NOR 10: $\mathrm{R} \leq 15 ; \mathrm{I}: 16-20 ; \mathrm{S} \geq 21$ & $0.0 \pm 0.0$ & $\mathrm{R}$ & $12.7 \pm 0.6$ & $\mathrm{R}$ & $9.5 \pm 0.7$ & $\mathrm{R}$ & $13.3 \pm 1.1$ & $\mathrm{R}$ & $0.0 \pm 0.0$ & $\mathrm{R}$ & - & - \\
\hline TE 30: $\mathrm{R} \leq 14 ; \mathrm{I}: 15-18 ; \mathrm{S} \geq 19$ & $0.0 \pm 0.0$ & $\mathrm{R}$ & $0.0 \pm 0.0$ & $\mathrm{R}$ & $0.0 \pm 0.0$ & $\mathrm{R}$ & $0.0 \pm 0.0$ & $\mathrm{R}$ & $17.3 \pm 3.1$ & I & - & - \\
\hline TMP 5: $\mathrm{R} \leq 10 ; \mathrm{I}: 11-15 ; \mathrm{S} \geq 16$ & $19.0 \pm 1.4$ & $\mathrm{~S}$ & $0.0 \pm 0.0$ & $\mathrm{R}$ & $0.0 \pm 0.0$ & $\mathrm{R}$ & $0.0 \pm 0.0$ & $\mathrm{R}$ & $0.0 \pm 0.0$ & $\mathrm{R}$ & - & - \\
\hline FLU 100 & - & - & - & - & - & - & - & - & - & - & $23.5 \pm 2.1$ & S \\
\hline GRS 10 & - & - & - & - & - & - & - & - & - & - & $0.0 \pm 0.0$ & $\mathrm{R}$ \\
\hline KTC 10 & - & - & - & - & - & - & - & - & - & - & $31.0 \pm 1.4$ & $\mathrm{~S}$ \\
\hline NY 100 & - & - & - & - & - & - & - & - & - & - & $15.5 \pm 0.7$ & $\mathrm{R}$ \\
\hline
\end{tabular}

Values are mean \pm SD. (-) = not tested, CIP 30: Ciprogloxacin, NOR 10: Norfloxacine, CRO 30: Ceftriaxone, CTX 30: Cefotaxime, DO 30: Doxycycline, TE 30: Tétracycline, TMP 5: E 15: Erytromycin, MET 50: Metronidazole, AMC 30: Amoxicilin + acide clavunilique, CN120: Gentamicine, C: Chloramphénicole NY 100: Nystatine, FLU 100: Fluconazole, GRS 10: Grisefluvin, KTC 10: Kétoconazole.

\subsection{Antimicrobial Activities}

\subsubsection{Inhibition Zone Diameters}

Table 6, below present inhibition zones diameters ( $\mathrm{mm})$, a bacterium or a yeast strain was considered susceptible to an extract when the tested extract exhibited on it an inhibition zone diameter equal to $7 \mathrm{~mm}$ and to $10 \mathrm{~mm}$ respectively [13]. The results show that at a concentration of $50 \mathrm{mg} / \mathrm{ml}$, only two extracts of the tested plants PF, CA showed no activity on all the pathogens. While the rest of the plant extracts SE, NP, DL, PN, RB, and RA were active on at least $50 \%$ of tested strains with inhibition zone diameters ranging from $7.67 \pm 0.58$ to $24.33 \pm 1.15 \mathrm{~mm}$. only $P$. nitida, could inhibit the growth of $E$. coli on agar media. P. stuartii was resistant to gentamicin, the reference drug, confirming its natural resistance against gentamicin [14]. Comparing the activity of extracts with reference antimicrobial agents at the tested concentrations using diffusion method, $P N$ has an activity comparable to that of fluconazole $(\mathrm{p}<0.05)$. The same observation was made between gentamicin and the following extracts $R A, R B, D L$ on $S$. saprophiticus $(\mathrm{p}<0.05)$ as well as between gentamicin and $D L$ on $P$. vulgaris. However, the activity of most extracts was higher than that of gentamicin on the reference strain E. Coli JM109 and that of SE was higher than that of gentamicin on E. Coli JM109, P. stuartii, and S. saprophiticus.

Table 6. Inhibition zone diameters $(\mathrm{mm})$ of methanolic plant extracts on tested microorganisms.

\begin{tabular}{|c|c|c|c|c|c|c|c|}
\hline Substance tested & C. krusei & E. coli & E. Coli JM109 & P. aeruginosa & P. stuartii & P. vulgaris & S. saprophiticus \\
\hline $\mathrm{CA}$ & $0.00 \pm 0.00 \mathrm{a}$ & $0.00 \pm 0.00 \mathrm{a}$ & $0.00 \pm 0.00 \mathrm{a}$ & $0.00 \pm 0.00 \mathrm{a}$ & $0.00 \pm 0.00 \mathrm{a}$ & $0.00 \pm 0.00 \mathrm{a}$ & $0.00 \pm 0.00 \mathrm{a}$ \\
\hline DL & $15.00 \pm 0.00 \mathrm{~b}$ & $0.00 \pm 0.00 \mathrm{a}$ & $24.33 \pm 1.15 \mathrm{e}$ & $15.00 \pm 0.00 \mathrm{~d}$ & $14.67 \pm 0.58 \mathrm{c}$ & $17.33 \pm 1.15 \mathrm{~d}, \mathrm{e}$ & $16.33 \pm 0.58 \mathrm{~d}$ \\
\hline LS & $10.00 \pm 0.00 \mathrm{~b}$ & $0.00 \pm 0.00 \mathrm{a}$ & $22.00 \pm 2.00 \mathrm{~d}, \mathrm{e}$ & $10.00 \pm 0.00 \mathrm{c}$ & $0.00 \pm 0.00 \mathrm{a}$ & $13.33 \pm 1.15 b, c$ & $11.00 \pm 1.00 \mathrm{~b}$ \\
\hline NP & $14,67 \pm 1,53 b$ & $0.00 \pm 0.00 \mathrm{a}$ & $7.67 \pm 0.58 b$ & $10.00 \pm 0.00 \mathrm{c}$ & $0.00 \pm 0.00 \mathrm{a}$ & $0.00 \pm 0.00 \mathrm{a}$ & $13.33 \pm 1.15 b, c$ \\
\hline PF & $0.00 \pm 0.00 \mathrm{a}$ & $0.00 \pm 0.00 \mathrm{a}$ & $0.00 \pm 0.00 \mathrm{a}$ & $0.00 \pm 0.00 \mathrm{a}$ & $0.00 \pm 0.00 \mathrm{a}$ & $0.00 \pm 0.00 \mathrm{a}$ & $0.00 \pm 0.00 \mathrm{a}$ \\
\hline $\mathrm{PN}$ & $20.33 \pm 1.53 c$ & $12.00 \pm 0.00 \mathrm{~b}$ & $19.00 \pm 1.73 \mathrm{c}, \mathrm{d}$ & $9,00 \pm 0,00 \mathrm{~b}$ & $0.00 \pm 0.00 \mathrm{a}$ & $0.00 \pm 0.00 \mathrm{a}$ & $20.00 \pm 0.00 \mathrm{e}$ \\
\hline RA & $15.00 \pm 1.00 \mathrm{~b}$ & $0.00 \pm 0.00 \mathrm{a}$ & $21.67 \pm 1.53 \mathrm{~d}, \mathrm{e}$ & $15.33 \pm 0.58 \mathrm{~d}$ & $10.67 \pm 0.58 b$ & $13.67 \pm 1.53 \mathrm{~b}, \mathrm{c}$ & $16.00 \pm 0.00 \mathrm{c}, \mathrm{d}$ \\
\hline SE & $16.33 \pm 1.53 b$ & $0.00 \pm 0.00 \mathrm{a}$ & $24.00 \pm 1.00 \mathrm{e}$ & $15.00 \pm 0.00 \mathrm{~d}$ & $14.00 \pm 1.00 \mathrm{c}$ & $15.33 \pm 0.58 \mathrm{c}, \mathrm{d}$ & $19.33 \pm 1.15 \mathrm{e}$ \\
\hline GENTA* & NT & $23.00 \pm 1.00 \mathrm{c}$ & $11.33 \pm 1.15 b$ & $20.00 \pm 0.00 \mathrm{e}$ & $0.00 \pm 0.00 \mathrm{a}$ & $20.00 \pm 0.00 \mathrm{e}$ & $16.00 \pm 1.00 \mathrm{c}, \mathrm{d}$ \\
\hline FLUCO* & $21,67 \pm 1,53 \mathrm{c}$ & NT & NT & NT & NT & NT & NT \\
\hline DMSO & $0.00 \pm 0.00 \mathrm{a}$ & $0.00 \pm 0.00 \mathrm{a}$ & $0.00 \pm 0.00 \mathrm{a}$ & $0.00 \pm 0.00 \mathrm{a}$ & $0.00 \pm 0.00 \mathrm{a}$ & $0.00 \pm 0.00 \mathrm{a}$ & $0.00 \pm 0.00 \mathrm{a}$ \\
\hline
\end{tabular}

Values are mean \pm SD; DMSO: diluting solvent, NT (not tested) Cussonia arborea (CA), Dissotis longipetala (DL Lonchocarpus sepium (LS), Nauclea pobeguinii (NP), Picralima nitida (PN), Rumex albissinicus (RA), Rumex berqueatii (RB), Sapium ellypticum (SE), Psorospermum febrifigum (PF), *: reference drugs. Plant extract not carrying the same letter in a column are statistically different ( $>>0.05)$, and plant extract carrying the same letter in a column are statistically identical $(\mathrm{p}<0.05)$. Activities of extracts carrying letter $\mathrm{a}<\mathrm{b}<\mathrm{c}<\mathrm{d}<\mathrm{e}$

\subsubsection{Microdilution Tests: Inhibition Parameters (MIC, $M M C$, and MMC/MIC Ratio)}

Table 7 resumes minimum inhibitory concentrations
(MIC), minimum microbicidal concentrations (MMC) and MMC/MIC ratios of tested extracts on pathogens. MICs results showed that MICs ranged from 0.125 to $128 \mathrm{mg} / \mathrm{ml}$ for 
plant extracts, from 0.0005 to $0.016 \mathrm{mg} / \mathrm{ml}$ for gentamicin and that of fluconazole on C. krusei was $0.002 \mathrm{mg} / \mathrm{ml}$. Authors are not unanimous about standard cut-off points describing antimicrobial activities of crude extracts. Nevertheless, according to [15], an activity is considered to be significant if MIC values are below $0.1 \mathrm{mg} / \mathrm{ml}$ for crude extract and moderate when $0.1<\mathrm{MIC}<0.625 \mathrm{mg} / \mathrm{ml}$, considering this stringent classification, the activity of $S$. ellipticum, $R$. abyssinicus, and $D$. longipetala can be considered moderate since they show a MIC $\leq 0.25 \mathrm{mg} / \mathrm{ml}$ on two resistant strains $S$. aureus and C. krusei. An alternative criterion has been described by [16], which considers extracts having MIC values below $8 \mathrm{mg} / \mathrm{ml}$ to have noteworthy antimicrobial activity. Based on these previous reports, and considering the differences in methods used, as well as the level of resistance of microorganisms involved in the studies, the antimicrobial potential of the various extracts in this study has been categorized, as follow: $\mathrm{MIC}<1 \mathrm{mg} / \mathrm{ml}$ the plant extract was very active, $1 \geq \mathrm{MIC} \leq 8 \mathrm{mg} / \mathrm{ml}$, the plant extract was moderately active, $8>\mathrm{MIC} \leq 64 \mathrm{mg} / \mathrm{ml}$ were considered less active or with activity negligible, MIC $>64 \mathrm{mg} / \mathrm{ml}$ was not active. The table 7 below summarizes the categorization of the crude extracts of plants.

Table 7I. Categorization of the activity of plant extracts.

\begin{tabular}{|c|c|c|c|c|c|}
\hline Substance tested & Inactive $\mathrm{MIC}>64 \mathrm{mg} / \mathrm{ml}$ & Less active $8>M I C \leq 64 \mathrm{mg} / \mathrm{ml}$ & $\begin{array}{l}\text { Moderately Active } \\
1 \geq \mathrm{MIC} \leq \mathbf{8 m g} / \mathrm{ml}\end{array}$ & Very active $\mathrm{MIC}<1 \mathrm{mg} / \mathrm{ml}$ & total \\
\hline $\mathrm{CA}$ & 4 & 3 & 0 & 0 & 7 \\
\hline DL & 0 & 2 & 4 & 1 & 7 \\
\hline LS & 0 & 2 & 4 & 1 & 7 \\
\hline NP & 0 & 0 & 7 & 0 & 7 \\
\hline PF & 3 & 4 & 0 & 0 & 7 \\
\hline PN & 0 & 5 & 2 & 0 & 7 \\
\hline $\mathrm{RB}$ & 0 & 5 & 1 & 1 & 7 \\
\hline SE & 0 & 0 & 5 & 2 & 7 \\
\hline Total of plant & 7 & 23 & 26 & 7 & 63 \\
\hline
\end{tabular}

Cussonia arborea (CA), Dissotis longipetala (DL Lonchocarpus sepium (LS), Nauclea pobeguinii (NP), Picralima nitida (PN), Rumex albissinicus (RA), Rumex berqueatii (RB), Sapium ellypticum (SE), Psorospermum febrifigum (PF)

Sapium ellipticum showed the highest inhibitory activity. It was very active on two strains $S$. saprophiticus and $C$. krusei $(\mathrm{MIC}<1 \mathrm{mg} / \mathrm{ml}$ ), and moderately active on the rest of the strains with (MICs ranging from $1 \mathrm{mg} / \mathrm{ml}$ to $8 \mathrm{mg} / \mathrm{ml}$ ). The growth inhibition was bactericidal $\mathrm{MMC} / \mathrm{MIC} \leq 4$ on all the pathogens [10] (see Table 8) making it a good candidate for drug preparation. The phytochemical screening results showed that it contents alkaloids, saponins, tannins, and terpenoids which could explain the observed antimicrobial activities. These secondary metabolites exert their antimicrobial activity through different mechanisms; tannins for example act by iron deprivation, hydrogen bounding or non-specific interactions with vital proteins such as enzymes [17]. Some of characteristics of saponins include formation of foam in aqueous solutions, hemolytic activity, cholesterol binding properties and bitterness [18]. The antimicrobial mechanism of action of the alkaloids may be through DNA intercalation and inhibition of DNA synthesis through topoisomerase inhibition [18]. Some studies have been done on the isolation and characterization of biological active components of this specie [19] but very few studies have reported the antimicrobial activities of this plant. The methanolic extract has been found to be hepato-protective [20]. Anti-fungal activities of dichloromethane and aqueous bark extracts of Sapium ellipticum have been carried out in Tanzania [19]. But, to the best of our knowledge, antibacterial activities of methanolic extracts of this plant are reported here for the first time.

Nauclea pobeguinii was moderately active on all the seven tested pathogens with MICs comprised between $1 \mathrm{mg} / \mathrm{ml}$ and
$8 \mathrm{mg} / \mathrm{ml}$, and the inhibition was bactericidal on all these strains. The plant was found to contain steroids, saponins and tannins which could explain the activities observed [18, 21]. Antimicrobial activity of the bark extract of this plant, using the microdilution method, presented better results than well diffusion method. This could be explained by a limited diffusion of the extract in the agar. To the best of our knowledge, antibacterial and antifungal activities of this plant are reported here for the first time. However, previous studies demonstrated a moderate antiplasmodial activity [22]; Moreover antioxidant activities of methanol bark extract of N. pobeguinii has been reported [23].

Dissotis longipetala was very active on S. saprophiticus, $(\mathrm{MIC}=0.25 \mathrm{mg} / \mathrm{ml})$ and the inhibition was bactericidal. It was moderately active on $C$. krusei, P. stuartii, P. vulgaris and E. coli, (MIC $\leq 8 \mathrm{mg} / \mathrm{ml}$ ); and less active on $P$. aeruginosa, and E. coli JM109 The phytochemical screening of this plant showed that it contains tannins, alkaloids and saponins, hence the antimicrobial properties demonstrated by this plant could be attributed to some of these biological active components [17-18]. This plant was reported to have very important antioxidant and reducing power [23] but the antimicrobial properties of the plants are reported here for the first time.

$R$. abyssinicus was very active on $S$. saprophiticus and $C$. krusei, $\mathrm{MIC}=0.25 \mathrm{mg} / \mathrm{ml}$, and the inhibition was bactericidal on $S$. aureus $(\mathrm{MBC} / \mathrm{MIC}=1)$ and bacteriostatic on $C$. krusei $(\mathrm{MMC} / \mathrm{MIB}=8)$ [10]. The extract was moderately active (MIC $\leq 8 \mathrm{mg} / \mathrm{ml}$ ) on P. stuartii, P. vulgaris and E. coli JM109, while less active on $E$. coli, $P$. aeruginosa, this activities could be attributed to tannins and alkaloids contained by the 
plant [17-18]. Some studies have been reported on biological properties of this plant. Antimicrobial activities of this plant has previously been demonstrated on Salmonella typhymurium, Listeria monocytogens, Escherichia coli and Staphylococcus saprophiticus [24] an against streptococcus pyogenes, S. aureus, Coxsackie virus B3 and Influenza $A$ virus [25]. Our results are slightly different from those of [24], but this difference in susceptibility could be attributed to the inherent resistance factors of the test organisms [26], the strains we used were by demonstrated to be multidrug resistant (see table V above). Moreover, the difference could also be explained by the test procedure which was different [24]. Except these properties, this plant has been shown to have antioxidant properties [24], anticancer activities [24, 27] antihelmentic activities [28], diuretic and analgesic effects [29], antiplasmodial properties [30].

Picralima nitida was moderately active on two strains $(S$. saprophiticus and C. krusei) and less active on the rest of five strains. A good number of reports on antimicrobial activities of this plant and its derivatives have been published [31-34] and our results corroborate those of the literature [35-36].

Antimicrobial activities of the crude extracts of $R$. berquaetii, P. febrifugum and Cussonia arborea corroborate those of literature [24], however, on the best of our knowledge, the antimicrobial activities of the crude extracts of Lonchocarpus sepium are reported here for the first time and have shown moderate activities on four strains ( $\mathrm{MIC} \leq 8 \mathrm{mg} / \mathrm{ml})$.

Regarding the phytochemical screening results, all the extracts $(C A, P F, P N$, ) which show poor activity on the tested microorganisms were found to contain none or very few classes (in traces) of secondary metabolites tested during this work (see table 4). This remark sustains the hypothesis where by the antimicrobial activity of an extract is attributed to the secondary metabolites it contains $[10,17-18,21]$. On the same note, most extract which show good activities in this study were found to abundantly contain tannins. Therefore the antimicrobial activities of the extracts demonstrated here could be attributed to tannins.

The overall results of the MICs showed that apart from the strain which the MIC could not be determined, the MICs of gentamicin and fluconazole are lower compare to that of the various extracts, this could be explained by the fact the extract till contain some impurities which can hinder its activity in comparison with reference antimicrobial agent which are pure: biological active compounds.

\section{Conclusion}

The results of the present study provided evidence for the antibacterial and antifungal activities of the studied plant extracts and brought supportive data for future investigations that will lead to their use in urinary and genital tracts infections therapy, and other infections cause by these pathogens. The categorization of extract activities permitted us to select four of the plants as having important activities (Sapium ellipticum, Nauclea pobeguinii, Dissotis longipetala and Rumex abyssinicus) having demonstrated a MIC $\leq$ $8 \mathrm{mg} / \mathrm{ml}$ on at least five of the eight tested pathogens. They were therefore kept for further investigations. This study also revealed the presence of various phytochemical groups in various plants, but tannins have been shown as responsible of the observed activities.

Table 8. Minimal Inhibitory Concentrations (MIC), (mg/ml) Minimal Microbicidal Concentrations (MMC) and the ratios MMC/MIC of plant extracts and reference drugs on tested pathogens.

\begin{tabular}{|c|c|c|c|c|c|c|c|c|c|c|c|c|}
\hline \multirow[b]{2}{*}{ EXTRACTS } & \multicolumn{3}{|c|}{ C. Krussei } & \multicolumn{3}{|l|}{ E. coli } & \multicolumn{3}{|c|}{ E. Coli JM109 } & \multicolumn{3}{|c|}{ P. aeruginosa } \\
\hline & MIC & MMC & $\begin{array}{l}\text { MMC/ } \\
\text { MIC }\end{array}$ & MIC & MMC & $\begin{array}{l}\text { MMC/ } \\
\text { MIC }\end{array}$ & MIC & MMC & $\begin{array}{l}\text { MMC/ } \\
\text { MIC }\end{array}$ & MIC & MMC & $\begin{array}{l}\text { MMC/ } \\
\text { MIC }\end{array}$ \\
\hline $\mathrm{CA}$ & 64 & 128 & 2 & 64 & ND & ND & 128 & $\mathrm{ND}$ & ND & 128 & ND & ND \\
\hline DL & 1 & 1 & 1 & 8 & 128 & 16 & 16 & 32 & 2 & 16 & 32 & 2 \\
\hline LS & 4 & 4 & 1 & 16 & 64 & 4 & 32 & 64 & 2 & 64 & 64 & 1 \\
\hline NP & 1 & 8 & 8 & 1 & 8 & 8 & 8 & 8 & 1 & 8 & 16 & 2 \\
\hline $\mathrm{PF}$ & 16 & 128 & 8 & 64 & ND & ND & 128 & 128 & 1 & 128 & 128 & 1 \\
\hline RA & 0.25 & 2 & 8 & 32 & 64 & 2 & 8 & 4 & 2 & 64 & 64 & 1 \\
\hline $\mathrm{RB}$ & 0.25 & 2 & 8 & 32 & 128 & 4 & 32 & 64 & 2 & 64 & 64 & 1 \\
\hline SE & 0.25 & 0.25 & 1 & 8 & 32 & 4 & 8 & 16 & 2 & 4 & 8 & 2 \\
\hline GENTA & NT & NT & NT & 0.0005 & 0.0005 & 1 & ND & ND & ND & 0.002 & 0.002 & 1 \\
\hline FLUCO & 0.002 & 4.00 & 2.00 & $\mathrm{NT}$ & NT & NT & NT & NT & NT & NT & NT & NT \\
\hline DMSO & ND & ND & ND & ND & ND & ND & ND & ND & ND & ND & ND & ND \\
\hline
\end{tabular}

Table 8. Continue.

\begin{tabular}{|c|c|c|c|c|c|c|c|c|c|}
\hline \multirow{2}{*}{ EXTRACTS } & \multicolumn{3}{|c|}{ P. stuartii } & \multicolumn{3}{|c|}{ P. vulgaris } & \multicolumn{3}{|c|}{ S. saprophiticus } \\
\hline & MIC & MMC & ММС/MIC & MIC & MMC & MMC/MIC & MIC & MMC & MМC/MIC \\
\hline $\mathrm{CA}$ & 128 & ND & ND & 64 & ND & ND & 128 & ND & 1 \\
\hline DL & 4 & 32 & 8 & 8 & 32 & 8 & 0.25 & 0.5 & 2 \\
\hline LS & 16 & 32 & 2 & 8 & 32 & 4 & 8 & 16 & 2 \\
\hline NP & 4 & 8 & 2 & 4 & 16 & 4 & 1 & 4 & 4 \\
\hline $\mathrm{PF}$ & 64 & ND & ND & 64 & ND & ND & 128 & 128 & 1 \\
\hline $\mathrm{PN}$ & 32 & 64 & 2 & 32 & 64 & 2 & 2 & 4 & 2 \\
\hline RA & 8 & 32 & 4 & 8 & 128 & 16 & 0.25 & 0.25 & 1 \\
\hline
\end{tabular}




\begin{tabular}{|c|c|c|c|c|c|c|c|c|c|}
\hline \multirow{2}{*}{ EXTRACTS } & \multicolumn{3}{|c|}{ P. stuartii } & \multicolumn{3}{|c|}{ P. vulgaris } & \multicolumn{3}{|c|}{ S. saprophiticus } \\
\hline & MIC & MMC & MMC/MIC & MIC & MMC & MMC/MIC & MIC & MMC & MMC/MIC \\
\hline $\mathrm{RB}$ & 32 & 64 & 2 & 16 & 64 & 4 & 2 & 4 & 2 \\
\hline SE & 1 & 2 & 2 & 2 & 2 & 1 & 0.12 & 0.25 & 2 \\
\hline GENTA & 0.016 & 0.032 & 2 & 0.005 & 0.0005 & 1 & 0.0025 & 0.0025 & 1 \\
\hline FLUCO & NT & NT & NT & NT & NT & NT & NT & NT & NT \\
\hline DMSO & ND & $\mathrm{ND}$ & ND & ND & ND & ND & ND & ND & ND \\
\hline
\end{tabular}

Values are mean; ND: not determined NT (not tested) (the value is higher than the highest concentration tesded) -: Untested Cussonia arborea (CA), Dissotis longipetala (DL), Lonchocarpus sepium (LS), Nauclea pobeguinii (NP), Picralima nitida (PN), Rumex albissinicus (RA), Rumex berqueatii (RB), Sapium ellypticum (SE), Psorospermum febrifigum (PF), *: reference drugs, DMSO: diluting solvent

\section{References}

[1] WHO, 2013. Sexually transmitted Infections, help memory $\mathrm{N}^{\circ}$ 110 May 2013.

[2] WHO, 2013. 2013 Worldwide health statistics.

[3] Fokunang CN, Ndikum V, Tabi OY, Jiofack, R. B, Ngameni B, Guedje N. M, Tembe Fokunang, E. A1, Tomkins, Barkwan S, Kechia, F, Asongalem E, Ngoupayou J, Torimiro NJGonsu KH1, Sielinou V, Ngadjui BT, Angwafor III F, Nkongmeneck A, Abena OM, Ngogang J, Asonganyi T, Colizzi V., Lohoue J, Kamsu-Kom, (2011). "Traditional medicine: past, present and future research and development prospects and integration in the national health system of Cameroon". African Journal of Traditional, Complementary and Alternative Medicine. 2011. 8 (3): 284-295.

[4] Assob JCN, Kamga HLF, Nsagha DS, Njunda AL, Nde FP, Asongalem AE, Njouendou AJ, Sandjon B, and Penlap BV. "Antimicrobial and toxicological activities of five medicinal plant species from Cameroon Traditional Medicine". BMC Complementary and Alternative Medicine. 2011.11: 70.

[5] Trease GE., Evans WC. Pharmacognosy, 12 edn. London: BailliereTindall. 1983.

[6] Cheesbrough M. District Laboratory Practice in Tropical Countries Part 2. Second Edition 2006.

[7] Bauer, A. W., Kirby W. M. M., Sherries, J. C. and Tuck, M. "Antibiotic susceptibility testing by a standardized disc diffusion method". American Journal of Clinical Pathology, 1966. 45: 493-496.

[8] Cos PM, Sindambiwe LW, Vlietinck AJ, Berghe DV: In Bioassays for Antibacterial and Antifungal Activities. Edited by: Mahabir P, Gupta S, Swami H, and Karan V. "Biological Screening of plant constituents". Training manual, International centre for science and high technology. Trieste; 2006: 19-28.

[9] Odeh IC and Anyiin TA. "Phytochemical and antimicrobial evaluation of leaf-extracts of Pterocarpus santalinoides". European Journal of Medicinal Plants. 2014.4 (1): 105-115.

[10] Marmonier AA. «Introduction aux techniques d'étude des antibiotiques». Bactériologie Médicale, technique usuelles. 1990. 227-236.

[11] Cowan M. M., "Plant Products as antimicrobial Agents". Clinical Microbiology reviews. 1999. 12 (4), 564-582.

[12] WHO. "Antimicrobial resistance: global report on surveillance" 2014.

[13] Nascimento GGF, Lacatelli J, Freitas PC, Silva GL.
"Antibacterial activity of plant extracts and phytochemicals on antibiotic-resistant bacteria". Braz. Journal of Microbiology. 2000. 31 (4): 886-891.

[14] Afssps (Agence Française de sécurité sanitaire des produits de santé). «Spectre d'activité antimicrobienne». 2005. 251P.

[15] Kuete V. "Potential of Cameroonian Plants and Derived Productsagainst Microbial Infections": A Review. Planta Medica. 2010. 76: 1479-1491.

[16] Fabry W, Okemo PO, Ansorg R. "Antibacterial activity of East African medicinal plants". Journal of Ethnopharmacology, 1998. 60: 79-84.

[17] Scalbert A. "Antimicrobial properties of tannins". Phytochemistry. 1991. 30: 3875-3883.

[18] Doherty, V. F. Olaniran, O. O, Kanife U. C. "Antimicrobial Activities of Aframomum Melegueta (Alligator Pepper)". International journal of biology. 2010. 2 (2): 126-131.

[19] Kisangau DP, Hosea KM, Lyaruu HVM, Joseph CC, Mbwambo ZH. "Screening of traditionally used Tanzanian medicinal plants for antifungal activity". Pharmaceutical Biology. 2009. 47: 708-716.

[20] Njouendou AJ, Nkeng-Efouet AP, Assob NJC, Chouna JR, Veerapur V P, Thippeswamy BS, Badami S, Wanji S. "Protective effect of Autranella congolensis and Sapium ellipticum stem bark extracts against hepatotoxicity induced by thioacetamide". Pharmacologyonline. 2014. 2 (39) 38-47.

[21] Compean KL and Ynavez RA. "Antimicrobial activities of plant secondary metabolytes: A review". Research Journal of Medicinal Plants. 2014: 1-10.

[22] Mesia K, Cimanga RK, Dhooghe L, Cos P, Apers S, Totté J, Tona GL, Pieters L, Vlietinck AJ, Maes L. "Antimalarial activity and toxicity evaluation of a quantified Nauclea pobeguinii extract". Journal of ethnopharmacology, 2010. 131 (1): 10-6.

[23] Assob JCN, Njouendou AJ, Nkeng P E, Chouna JR, Badami S. M., Veeresh P V, Typpeswamy BD and Wanji S. In vitro screening of antioxidant properties of ten Cameroonian medicinal plants. Journal of Advances in Biotechnology. 2014. 3 (2): 171-182.

[24] Tamokou JD, Chouna JR, Fischer-Fodor E, Chereches G, Barbos O, Grigore D, Benedec D, Duma M, Nkeng EAP, Wabo KH, Kuiate JR, Mot A, Radu SD. "Anticancer and Antimicrobial Activities of Some Antioxidant-Rich Cameroonian Medicinal Plants". Plos one. 2013. 8 (2): 1-14.

[25] Getie M, Gebre-Mariam T, Rietz R, Höhne C, Huschka C, Schmidtke M, Abate A, Neubert RH. „Evaluation of the antimicrobial and anti-inflammatory activities of the medicinal plants Dodonaea viscosa, Rumex nervosus and Rumex abyssinicus". Fitoterapia: 2003.74 (1-2): 139-43. 
[26] Ekpo, M. A., Etim, P. C. "Antimicrobial activity of ethanolic and aqueous extracts of Sida acuta on microorganisms from skin infections". Journal of Medicinal Plant Research. 2009. 3 (9), 621-624.

[27] Worku N, Andualem M, Stich A, Daugschies A, Trettner S, Nasr YAH, and Gerd. Evaluation of the In Vitro Efficacy of Artemisia annua, Rumex abyssinicus, and Catha edulis Forsk Extracts in Cancer and Trypanosoma brucei Cells. ISRN Biochemistry, 2013: 1-11.

[28] Raju NJ, Yesuf EA). Evaluation of antithelmintic activities of Rumex abyssinicus jacq and Rumex nervosus vahl. (polygonaceae). International Journal of Pharmaceutical Sciences Review and Research, 2010. 5 (2): 55-57.

[29] Mekonnen T, Urga K, Engidawork E. Evaluation of the diuretic and analgesic activities of the rhizomes of Rumex abyssinicus Jacq in mice. Journal of ethnopharmacology. 2010. 127 (2): 433-9.

[30] Muganga R, Angenot L, Tits M, Frédérich M Antiplasmodial and cytotoxic activities of Rwandan medicinal plants used in the treatment of malaria. Journal of ethnopharmacology. 2010. 128 (1): $52-57$.

[31] Iwu MM, Klayman DL. "Evaluation of the in vitro antimalarial activity of Picralima nitida extracts". Journal of
Ethnopharmacoly. 2002. 36 (2): 133-135.

[32] Ubulom P., Akpabio, E., Udobi C. E., Mbon, R. "Antifungal Activity of aqueous and ethanolic extracts of Picralima nitida seeds on Aspergillus flavus, Candida albicans and Microsporum canis". Research in Pharmaceutical Biotechnology. 2011.3 (5), 57-60.

[33] Kouam J, Mabeku LBK, Kuiate JR, Tiabou AT, Fomum ZT. "Antimicrobial glycosides and derivatives from roots of Picralima nitida". International Journal of Chemistry. 2011. 3: 23-31.

[34] Erharuyi O, Falodun A and Langer P. "Medicinal uses, phytochemistry and pharmacology of Picralima nitida (Apocynaceae) in tropical diseases: A review". Asian Pacific Journal of Tropical Medicine. 2014. 1-8.

[35] Fakeye TO, Itiola OA, Odelola HA. "Evaluation of the antimicrobial property of the stem bark of Picralima nitida (Apocynaceae)". Phytotherapy research. 2000. 14 (5): 368-70.

[36] Nkere CK, Iroegbu CU. "Antibacterial screening of the root, seed and stem bark extract of Picralima nitida". African Journal of Biotechnology. 2005.4 (6): 522-526. 